\title{
THE INDUSTRIAL POLITICS OF DISABLEMENT
}

In 1843, one year after Parliament had passed the landmark Mines and Collieries Act banning females and children under the age of 10 from working underground, Punch magazine printed a cartoon titled 'Capital and Labour' (Figure 4). Reflecting the magazine's sympathy for the poor and downtrodden and the spirit of social justice that characterised its radical early years, the image contrasted the circumstances of those who grew rich from coalmining, the wealthy coal owners, with those whose work brought their profits. Beneath the soft opulence of the capitalist's dwellings is depicted a prison-like coal mine, populated by the vulnerable and impaired: starving ragged children, a frightened-looking woman holding a baby to her breast, an old man with twisted limbs bent double, another on crutches, another lying broken and exhausted on the ground. Watched over by a fat gaoler who collected the employer's 'gold', this was a world from which hope and love were firmly shut out - as shown by their allegorical figures, pictured to the left of the underground scene, pushing at a locked door. ${ }^{1}$

Punch's cartoon referenced the vivid images of working conditions included in the Children's Employment Commission Report, which had caused a press sensation on their publication in May 1842. The Report's depiction of the 'dismal chambers' in which men, women and children worked, in tasks that required 'the severest exertions' to complete, exposed the rigours of mine work to horrified legislators and members of the public. ${ }^{2}$ Although it was not the first official publication to recognise the dangers of coalmining, the report represented a key moment in the emergence of the cultural figure of the disabled mineworker. This figure was used rhetorically to great effect by policymakers and critics of industrialisation during the frequent debates about mining regulation that punctuated the nineteenth century. In persuading Parliament to outlaw the underground employment of women and young children in 1842, 


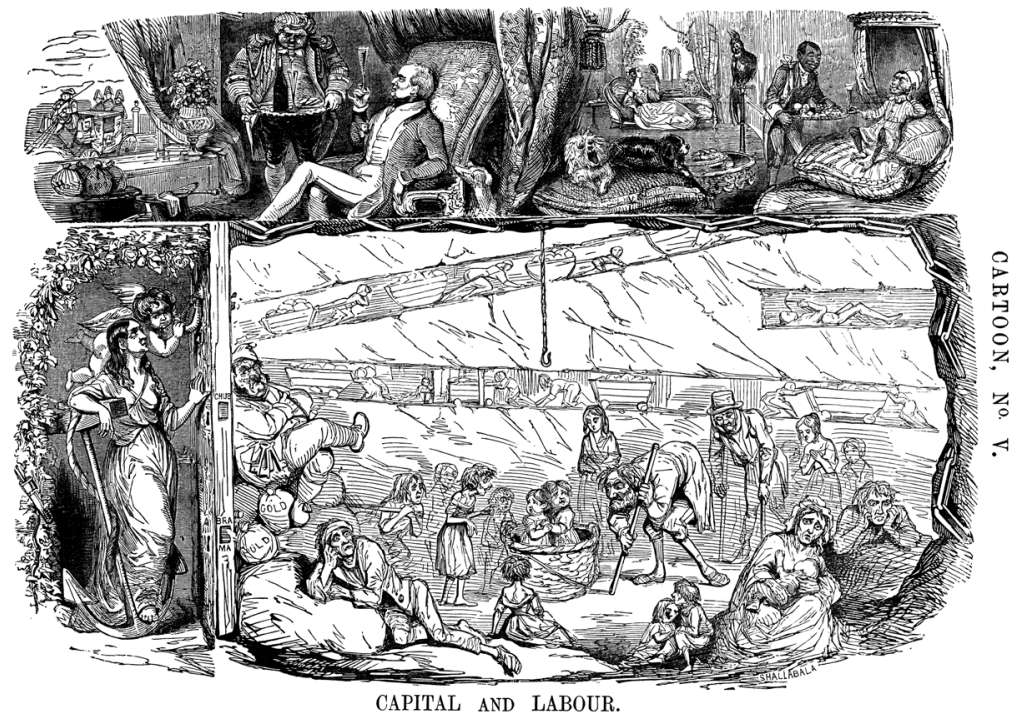

Figure 4 'Capital and Labour', Punch, 29 July 1843. Reproduced with the permission of Punch Ltd. Punch.co.uk.

the law's chief architect, Lord Ashley, drew heavily on the report's evidence of the injurious effects of mine work, citing statements about the 'fatigue', 'deformity', 'distorted' spines and other assorted injuries and diseases suffered by mine-working women and children. ${ }^{3}$ Such references helped supporters of industrial reform win their argument in 1842 and testified to the power of the image of the disfigured and disabled coal worker in the popular imagination.

As we have seen, at one level the 1842 Mines and Collieries Act was a piece of moral legislation, intended to end the exploitation of very young children in collieries and also to reinforce Victorian domestic ideology. By ending female work underground, it was hoped the law would encourage women and girls to remain at home, where it was thought they belonged. Yet the 1842 Act was about much more than promoting gendered social roles. As the law stated, one of its main goals was to 'make Provisions for the safety' of mineworkers - by mandating, for example, age limits on tasks such as the operation of shaft engines. ${ }^{4}$ The Act also empowered an inspector to enter a coal mine to check whether the provisions of legislation were 'properly observed' and report any breaches to the Home Office. ${ }^{5}$ Although the appointment of only one inspector, Hugh Seymour Tremenheere, to monitor all mines in Britain was clearly inadequate, over the course of the following thirty years government 
regulation of coalmining was progressively extended. ${ }^{6}$ This included the establishment in 1850 of a more comprehensive Mines Inspectorate with greater powers to fine coal owners for non-compliance with safety recommendations and (as we saw in Chapter 1) the better documentation of fatal accidents and 'serious injuries'. Aimed as they were at reducing or documenting the number of accidents, such measures indicate policymakers' growing concerns about industrial death and injury in the nineteenth century and their willingness to do something about it.

As Catherine Mills has shown, the tightening of laws around mining safety and inspection owed much to high occupational mortality, the increasing visibility of risk, and developing medical knowledge about miners' susceptibility to illnesses such as lung disease. Legislative action was not only down to the goodwill of legislators', but also stimulated by a combination of public sympathy and trade union activism spurred on by the extension of the franchise. ${ }^{8}$ Legal reforms also reflected shifting ideas in political economy. As we have seen, at the beginning of the nineteenth century it was widely believed that miners' relatively good wages compensated them for the higher risks they faced, which, taken together with the employer paternalism examined in previous chapters, negated the demand for government regulation to protect health and safety. ${ }^{9}$ However, over the course of the century this was gradually replaced by the idea that workers were 'bodily capital' that needed protecting in the interests of national prosperity and competitiveness. Mine and factory regulation shifted over the course of the middle part of the nineteenth century away from a narrow and paternalistic concern with the health and moral well-being of women and children, towards interventions that sought to protect the health and productivity of all workers, including men. ${ }^{10}$ While the prevention of fatalities remained a priority of policymakers, safety regulations that would reduce non-fatal injuries as well were introduced. By 1872, mines were required to have at least two shafts to ensure ventilation and emergency access, and managers were obliged to take measures to 'secure' roofs and fence off machinery. ${ }^{11}$ Not only did these reforms try to prevent or reduce the number of accidents, they also came to define the responsibilities of the interests of 'Capital' to men and women of 'Labour' in compensating those injured in the workplace.

The history of mining regulation has been well documented, but few accounts have explored the place of disability in nineteenth-century coalfield industrial relations. As Sarah Rose points out, as valuable as state-centred accounts of disability policies and politics are, they tend to overlook the experiences of disabled people and the role they have played in shaping their own lives. Over the course of this period, miners and their representatives 
became increasingly vocal in drawing attention to the daily threats posed to their 'lives and limbs' in the coal mines. In its use of broken bodies to depict the injustices of capitalism, Punch's cartoon represented in visual form a rhetoric of disability that was increasingly used in the nineteenth century as a rallying call for men to combine in local or national trade unions. Disablement, as we shall see, was represented as a shared risk that bonded working people together in a common experience of suffering. ${ }^{12}$ Exploring both local and national campaigns, this chapter examines the ways in which unions took up the cause of disabled miners and provided their own systems of support. It also examines the political agency of disabled miners themselves and explores their experiences of industrial conflict. Although we should not exaggerate the extent of trade union membership or political activism among Britain's coalminers before 1880, fluctuating relations between employers and mineworkers often affected the lived experiences of disabled people in dramatic ways. ${ }^{13}$ For many miners, the industrial politics of disablement played out in local settings and was concerned not just with working conditions, but also how those left injured or permanently impaired were treated. Industrial relations raised questions of responsibility and loyalty, in which miners' expectations of their employers - and their fellow workmen - came under scrutiny.

This chapter asks how seriously labour leaders and employers took the needs of disabled workers. Both sides frequently proclaimed they had the best interests of disabled workers at heart. Nevertheless, nineteenth-century coal owners and mining unions were often prepared to sacrifice the immediate needs of sick and injured miners in pursuit of victory in the heated industrial conflicts in which they were frequently engaged. Disabled miners and their families - like inhabitants of mining communities more generally - undoubtedly faced increased hardships during strikes. However, periods of intense industrial conflict may not always have been unmitigated disasters for disabled people. On the contrary, this chapter presents evidence that industrial disputes may have presented disabled mineworkers with opportunities that some chose to exploit.

\section{Disability and industrial relations: the voices of labour}

The years following the repeal of the repressive Combination Laws of the Napoleonic era in 1824 witnessed an 'upsurge of trade union organisation', especially among colliers. ${ }^{14}$ Miners' concerns about injury and illness were central to this organisational activity. In order to attract members, many mining unions included sick pay among the benefits they offered. For example, in the 1830s, Thomas Hepburn's Union of Miners in north-east England 
offered sickness benefits to those who joined. During the cholera epidemic of 1831-32, this commitment to members proved a serious drain on the union's financial resources and undermined its ability to maintain effective strike action. By mid-1832, the union was spending almost 40 per cent of its income on sickness and death benefits. ${ }^{15}$

As John Benson has shown, after 1850 a significant majority of English mining unions operated sickness and accident funds. These funds had three main purposes. First, they aimed to attract members by offering a benefit that would appeal to miners given the dangers of their occupation. Second, based as they were on mutualist principles, such benefits sought to promote solidarity and fraternal feelings among members. Third, sickness and accident pay was intended to reduce miners' dependence on employer-controlled schemes such as pit clubs. More than simply a pragmatic response to ill health or injury, then, union provisions for sick or injured members aimed to maintain the dignity, independence and self-determination of workers that was essential for the success of trade unionism. ${ }^{16}$ Like other self-help schemes, however, trade unions were not very good at providing long-term support for permanently disabled members. In 1872, for example, the Durham Miners' Association promised five shillings a week to members incapacitated for work for the first six months of incapacity, falling to half that amount thereafter. After a year, the weekly benefit fell further still, to two shillings, 'so long as such a person be unable to resume work'. ${ }^{17}$

Mirroring friendly societies, trade union funds also often imposed moral clauses on their members that aimed to uphold the ideal of the careful, responsible worker. In Scotland, the Larkhall Miners' Mutual Protection, Accident and Funeral Association, founded in 1874, for example, emphasised 'mutual support', including making provision for 'members when disabled by accident in following their employment', but fined men who were found drunk at work or were deemed 'guilty of any grossly culpable act while on duty'. Worse still, offenders could lose their right to benefits for up to three months, depending on the will of the association's Board of Management. ${ }^{18}$ Members who endangered their workmates, or were injured through their own irresponsibility, then, were stigmatised. As mine workings became more extensive, it became increasingly difficult for workers to monitor their colleagues' behaviour, and therefore such rules were intended to foster self-regulation in the interest of collective safety. Organised labour demanded a disciplined workforce. ${ }^{19}$

Aside from providing their own support for sick or impaired members, unions pressed for better provision for the injured from employers. As we have seen, Durham and Northumberland miners injured at work were customarily paid allowances of 'smart money' by their employers during periods 
of incapacity. Workers and mine owners frequently disagreed on the basis and extent of such incapacity benefits and disputes over smart money were common. Miners preferred to see sick pay as their right, regarding it as part of their remuneration package for the dangerous work they did. Mine owners, in contrast, tended to view smart money as a 'gratuity', a generous gesture of goodwill towards employees that could be withdrawn whenever they chose. ${ }^{20}$ Such differences of opinion were usually expressed most dramatically and vociferously during strikes. As early as 1793, striking mineworkers at Hartley Colliery, Northumberland, included in their list of demands a call for five shillings a week for injured pitmen. The strikers claimed this would bring the pit into line with the provisions made for injured miners at other collieries in the region. ${ }^{21}$

Despite such early efforts, north-east England miners' entitlement to smart money remained very uncertain well into the next century. ${ }^{22}$ In 1825 , pitmen from Thomas Hepburn's newly founded United Association of Colliers complained 'of having no "smart money" or weekly allowance, made to us, when we have been lamed in following the work of our employer'. ${ }^{23}$ Even at pits where owners routinely paid such allowances, there were frequent disagreements about the amount of smart money on offer. During the great strike of 1844, disgruntled colliers in Northumberland and Durham, for instance, included a doubling of smart money from five to ten shillings a week among the list of demands they presented to mine owners. ${ }^{24}$

While financial mitigation of the effects of injury was a priority for many pitmen, the improvement of mine safety also played a significant role in the industrial politics of mining in the nineteenth century. Indeed, the two issues were often intimately linked in the minds of miners. When striking colliers in north-east England demanded more smart money in 1844, they publicly reasoned this would 'cause greater care to be taken of [their] lives and limbs'. For these pitmen, sick pay was not simply a matter of financial support during incapacity; it was also seen as a spur to mine owners to improve colliery safety. Miners hoped that by increasing the financial burden accidents placed on owners, an increase in smart money allowances would incentivise mining companies to invest in accident prevention measures, such as better ventilation. ${ }^{25}$

Indeed, worries about poor ventilation were a frequent theme in mining union complaints about working conditions at British collieries throughout the nineteenth century. When Hepburn's union stated the 'various grievances of the pitmen of the Tyne and Wear' in 1825, it not only called for smart money; it also highlighted the dangers of bad ventilation to the lives and health of miners. ${ }^{26}$ As English colliers commonly complained of the 'pernicious' health effects of work in poorly ventilated mines, so too did colliers in 
other parts of Britain. ${ }^{27}$ According to Mines Inspector Tremenheere, ' $[\mathrm{t}]$ he injurious effect of badly ventilated pits upon the health of the people working in them was one of the prominent subjects of complaint put forward by the delegates of the Miners' Union in Scotland in 1844 ' ${ }^{28}$ Miners' demands for improved health and safety measures were especially loud following major mining disasters. Within a few months of the Hartley Colliery catastrophe in which more than 200 people died, mostly from suffocation after being trapped underground due to the mine's single shaft being blocked by fallen machinery, a petition signed by 17,000 miners was presented to Parliament urging better government regulation of mining safety. ${ }^{29}$

Such campaigns were an increasingly significant and frequently successful component of organised labour's struggle for better colliery safety from the 1840s. Coalminers were among the first Victorian workers to demand state intervention in their industry. ${ }^{30}$ After the enactment of the Mines and Collieries Act of 1842, miners' leaders came to realise that government could, if handled carefully, be a useful ally in industrial politics and an effective protector of workers' health and safety. This realisation was particularly influential in the wake of the crushing defeat of pitmen in the great strike of 1844, when miners were forced to rethink their strategy for bringing about change. Following the strike, miners began to turn more to the state for help, petitioning lawmakers directly rather than simply battling coal owners and their entrenched interests in the coalfields. The passage of the 1850 Mines Inspection Act owed much to this new approach, as pitmen - through the Miners' Association of Great Britain and Ireland - lobbied Parliament, assisted by allies such as radical MP Thomas Slingsby Duncombe, to great effect. ${ }^{31}$

As their petition after the Hartley disaster of 1862 indicates, miners commonly pointed to shocking colliery accidents in the sector to put pressure on legislators to do something to protect them. ${ }^{32}$ These had the power to provoke public sympathy and were widely reported in the press. Yet alongside disturbing tales of underground deaths, unions' growing interest in influencing industrial politics through appeals to the state meant images of industrial disease and deformity highlighted by government investigations of mine work were also powerful rhetorical tools. At the start of the great strike of 1844, speakers at a mass meeting held near Gateshead used imagery reminiscent of the 1842 Children's Employment Commission Report when they highlighted the ways in which miners' bodies had been worn down by 'toil' or hurried into 'premature old age' to support the justice of their cause. ${ }^{33}$ Such imagery was taken up by critics of industrial capitalism more generally. In his Condition of the Working Class in England of the same year, Friedrich Engels actually cited the work of the Children's Employment Commission directly to document 
the '[d]istortions', 'deformities' and 'malformations' suffered by mineworkers because of their work in the coal industry. In his view, the damaged bodies of miners were visual evidence of the 'shameless oppression of the "coal kings"' and proof of the evils of the emerging industrial system. ${ }^{34}$

As Engels' and striking miners' rhetorical use of the figure of the disabled miner in 1844 suggests, such imagery was also used to garner support for causes beyond health and safety and provision for disabled workers. By the early 1860 s, aided by pro-labour newspapers, such as John Towers' British Miner (which made a point of documenting every fatal mining accident), it became commonplace for miners and others to list lack of protection for our lives and limbs' alongside other grievances ranging from the truck system to disputes over the weighing of coals. ${ }^{35}$ Many correspondents to these newspapers argued that trade union combination was the only defence against the 'appalling amount of physical suffering' experienced by men who were 'slaughtered at the rate of 1000 a year [and] endure the pauperism resulting from 10,000 permanent disablements' caused by mine work. ${ }^{36}$ In an address to the miners of Staffordshire in May 1863, James Moon similarly cited examples of loss of life and 'fractured limbs and mutilated bodies' that left families without breadwinners and dependent on 'the pittance of the benevolent' or the Poor Law. He called for his fellow miners to 'come forward like men, and join in the association for the better protection of the health and lives of the working miners of Staffordshire'. The miners, Moon argued, were 'freeborn sons of Britain' and should not allow themselves to be treated like the 'serfs of Russia'. For Moon, union membership was a means of restoring manhood against miserable dependency. ${ }^{37}$ In spite of evidence that many injured miners found work in the industry, supporters of combination frequently represented disability through the lens of 'suffering', as something that would lead inevitably to impoverishment and devaluation. Unionisation campaigns commonly played on fear of impairment to drum up support. In this context, as Rose has argued, the rhetoric of workplace disability served as a 'narrative prosthesis' - a crutch to support calls for political mobilisation on a range of occupational grievances. ${ }^{38}$ While these representations employed death, disease and disability to critique rapacious industrial capitalism, they had little to say about the day-to-day lives of disabled coalminers.

As important as unions were in harnessing and shaping nineteenth-century mineworkers' fears and responses to industrial disability, they are not the whole story. The presence and impact of unions in the coalfields at this time ebbed and flowed and were never uniform. In the first half of the century, pits in the north-east of England tended to be the hotbeds of mining unionism while miners in Scotland and especially south Wales were generally slower 
to organise. In 1844, two-thirds of the 32,000 members of the Miners' Association came from north-east England, while most of the remainder came from Lancashire and Yorkshire. ${ }^{39}$ As late as the mid-1860s, only a third of workers in British coalmining were unionised, and most of these were hewers. ${ }^{40}$ By 1900, despite an impressive upsurge in membership, union density in the industry was still only around three-fifths (59.5 per cent) of the total workforce. ${ }^{41}$ Despite their prominence in the historiography of coalmining, then, unions were not always the conduit through which industrial politics played out in the sector. ${ }^{42}$

Many miners acted independently on matters of health and safety, making decisions on their own or with their immediate work group colleagues about how best to protect their lives and bodies. At times, this meant they were prepared to defy colliery management and even the law. In October 1867 the Colliery Guardian reported the case of John Macmillan, a Durham mineworker prosecuted for breach of contract. Macmillan left his place of work at Washington Colliery without the consent of his employers. When asked to explain his actions in court, Macmillan 'complained that the atmosphere of the pit was so hot that his eyesight and head had been greatly affected, the giddiness resulting disabling him from performing his work'. When asked if he was willing to return to work, Macmillan stood by his original decision, insinuating that 'he had a wife and four children to consider'. Macmillan, then, seems to have made his unilateral decision to leave his station out of fear for his health and physical ability to support his family. The price he paid, moreover, suggests his worries were genuine and deep-rooted. For his intransigence, Macmillan was 'sent to prison for one month with hard labour'. ${ }^{43}$ Macmillan was certainly not alone in this regard. Edward Rymer, as we saw in Chapter 1, was also imprisoned for breaking his bond of employment after leaving a pit he saw as injurious to his health.

Unionised miners who fell foul of the law or tried to use it to mitigate the financial effects of impairment could not always rely on the support of their unions. Despite their rhetorical concern about disabled workers, labour leaders did not view all injured miners with sympathy. Giving evidence before a parliamentary committee on employers' liability for workplace injuries in April 1877, Benjamin Pickard, the secretary of the West Yorkshire Miners' Association, referred to the case of a mineworker burnt while working underground. The injured man had sought union assistance to sue his employer for compensation, but was refused because he had entered his place without clearance from his manager, as required by mine rules. In the eyes of Pickard and the union, this made the injured miner responsible for his own injuries, not his employer. ${ }^{44}$ Reactions like this again illustrate how notions of who was 
to blame for industrial disability could have a profound effect on the experiences of injured workers. As in the rules they wrote for union accident funds, labour leaders often displayed a moralistic attitude in their day-to-day dealings with injured miners. Mineworkers deemed culpable for their own injuries because of reckless behaviour were cast off. Rather than being seen as victims of industrial capitalism whose disabilities called for solidarity and collective action, they were viewed instead as individuals whose behaviour acted as a warning to others. Like the disabled nineteenth-century American railroad workers studied by John Williams-Searle, such men 'tested [the] boundaries of brotherhood' among miners. ${ }^{45}$ Unions, then, were not always useful, supportive or even sympathetic allies in the industrial politics of disability. Sometimes they were as recalcitrant and obstructive as the most difficult and uncaring employers.

\section{Industrial conflict as a cause of disability}

As the examples of labour unrest referred to above suggest, the British coal industry has a long history of fractious industrial relations. During the nineteenth century, most decades were marked by at least one serious and protracted dispute between mineworkers and employers. Strikes were common throughout the coalfields, major ones occurring, for example, at pits in north-east England, Scotland and south Wales in 1810, 1831-32, 1844, 1856 and $1871 .{ }^{46}$ Such disputes left their mark on the disability histories of British coalmining communities. On a somatic level, they often helped create impairment. As Rose notes, industrial disputes through the ages have frequently turned violent, leaving many workers seriously injured. ${ }^{47}$ The same is true for the British coal industry in the eighteenth and nineteenth centuries. ${ }^{48}$ Accounts of strikes and protests from the period are littered with references to violent and injurious incidents. In March 1789, Thomas Barnes, an 'agent for Walker Colliery' in Northumberland was set upon by protesting pitmen who 'beat him' so badly that he was 'disable[d] ... from working for some time'. ${ }^{4}$ Managers were not the only ones hurt in violent incidents like this. Workmen were also injured in heated industrial disputes such as the one at Ayrshire pits in 1842. Striking colliers there, according to a report in The Times, took umbrage to imported labour brought in to keep the mines open. Among those caught up in the tumult, were 'two men who had lately come to reside' in the area, presumably to work in a local colliery. One afternoon, on their way home after work, the two men were attacked 'by an incensed mob, who threw stones at them and seriously injured their persons' ${ }^{\prime}{ }^{50}$ Inhabitants of mining districts from all social classes frequently fell victim to similar acts of violence. ${ }^{51}$ 
Mineworkers with pre-existing physical impairments were not automatically insulated from workplace violence. In February 1832, collier David Edwards went to work in a coal pit attached to an ironworks at Blaina, south Wales. Many workers there were engaged in a dispute with their employer and were effectively on strike. Regarded as a blackleg, Edwards soon came to the attention of the notorious 'Scotch Cattle' - groups of Welsh miners who terrorised fellow workers that refused to take part in collective action - and received a beating for his troubles. When he gave evidence about his experiences in front of a local magistrate, Edwards declared that around the time of the attack he was 'lame and not able to walk as fast' as other workmen. Although having a mobility impairment did not ultimately save Edwards from violence, it may have stopped the attack from becoming more serious, as during the assault one member of the gang urged restraint on the others, saying Edwards 'was not guilty to be punished'. The court records remain unclear on this point, however, and it may be that the Cattle's leniency towards Edwards was more to do with fact that he had decided to stop work before the attack than his 'disability'. ${ }^{52}$ Whatever the case, it is clear that injured miners like Edwards could be hurt in industrial unrest just as other workers were. The passions aroused during heated disputes meant no one was completely immune from physical attack, not even people who in other contexts might expect to be treated with sympathy and kindness.

Disabled mineworkers were not only the victims of violence; sometimes they were involved in meting it out to others - and to great effect. In his memoir of his life as a mineworker, self-declared 'half-blind' and 'cripple' Edward Rymer recalled a physical altercation he had with one of his supervisors during a pay dispute in 1859. According to Rymer, his superior became aggressive and 'tried to force me out of the pit by an assault'. Rymer did not submit passively but 'retaliated' and a 'scuffle' ensued in which his surprised manager came off worse (in Rymer's reckoning, at least). ${ }^{53}$ Incidents such as these are a powerful reminder of the agency of disabled workers in industrialising Britain. Despite popular accounts of the Industrial Revolution, in which disabled people tend to feature as the passive victims of disruptive economic forces, this example suggests that not all workers with impairments were willing to be, quite literally, pushed from the workplace without a fight.

Some nineteenth-century Britons thought industrial disputes weakened the bodies of mineworkers in less direct ways. A witness to the great pitmen's strike of 1844 in north-east England claimed that many strikers 'so much reduced themselves by low living, that they were good for nothing for weeks after they started [work] again'. Inspector Tremenheere concurred with this view when he also reflected on the effects of the strike on the bodies of miners, 
noting that 'it was a long time before they recovered their former strength' ${ }^{54}$ Nearly three decades later, the secretary of a Welsh coal owners' association, Alexander Dalziel, made similar remarks in his observations on the south Wales' miners' strike of 1871 . The 'diminution of the physical power of the workmen' caused by the dispute, Dalziel wrote, was so serious that it took two months after their return to work 'before they could be said to have been restored to good working condition'. ${ }^{55}$ Late Victorian newspaper accounts of strikes sometimes depicted miners and their families as being so weak with hunger that they could not walk. ${ }^{56}$ Moreover, in an industry where the 'seasoning' of workers' bodies was important to making them strong and flexible enough to cope with the rigours of underground labour, absence from work, whether voluntary or enforced, could result in reduced somatic capabilities. In the view of many mine owners, managers and inspectors, the weakened physical capacities of mineworkers brought on by their idleness and abstemious living during strikes meant that prolonged industrial action was a cause of 'disability' (albeit temporarily) in its own right.

Strikes were also thought to increase the occupational risks to which miners were exposed on their return to work. In April 1827, British newspapers reported the deaths of at least five Scottish colliers when they inhaled noxious 'choke damp' following the reopening of a pit after a recent strike. The reports implied that the fatalities were a tragic consequence of the dispute because the cessation of mining operations during the strike had allowed deadly gases to build up through a lack of ventilation. ${ }^{57}$ The importation of blackleg labour to break strikes also aroused the suspicion of former strikers, who claimed it compromised their safety. In the aftermath of the Haswell Colliery disaster of September 1844, old hands employed before the strike of that year complained that the 'strange men' brought in from outside local pit villages to end the dispute might be to blame for the calamity. Their inexperience of conditions in the coalfield, so the argument went, meant they were incapable of spotting the tell-tale signs of underground dangers. This made them a liability not only to themselves, but also to the safety of other mineworkers. ${ }^{58}$ Such claims were common, though it is difficult to gauge their veracity given the acrimonious post-strike contexts in which they were often made. Yet, as Robert Colls points out, the 'disastrous aftermath' of the strikes in north-east England of 1831-32 and 1844 'offers some support for the “true-bred” pitmen's claims'. In the six months from May to November 1832, for example, four 'major explosions' occurred in the region. ${ }^{59}$ 


\section{Disabled people and industrial conflict}

Industrial disputes may have caused injuries, but what happened to people who already had impairments during such tumultuous times? The experiences of disabled people in coalfield communities during periods of industrial unrest were mixed. In some cases, intense conflict may have presented disabled mineworkers with better work opportunities; in others it resulted in increased hardships. For the courageous or desperate miner willing to work as a hated blackleg, strike-breaking could be a profitable, if risky, business. Accounts of nineteenth-century miners' strikes make clear that many mineworkers were indeed prepared to take such risks. Blackleg labour helped break numerous strikes, much to the chagrin of unionised workers. ${ }^{60}$

Miners with impairments were among those who took advantage of the opportunities for work afforded by strikes. Recall, for instance, the example of 'lame' collier David Edwards cited previously who went to work in the 1830s at a mine in Blaina despite workers there being on strike. Judging from his testimony about his encounter with the 'Scotch Cattle', it seems Edwards had been looking for work in the area unsuccessfully for some time before he took up employment at the pit. ${ }^{61}$ If Edwards' mobility impairment undermined his job prospects at collieries with relatively harmonious industrial relations, in the context of the dispute at Blaina it seems to have presented no major barrier to his participation in the mining workforce. Edwards was certainly not alone; other 'disabled' mineworkers also crossed picket lines to take up work during strikes. In his account of the 1844 strike in Northumberland and Durham through which he had lived, historian Richard Fynes recorded a fatal accident involving a visually impaired Welsh collier known as 'Blind Davy', who died after falling down a mineshaft. As one of the blacklegs brought in to break the strike, Davy's death was apparently little mourned by fellow workers, with one 'old furnaceman' remarking that the dead man was 'only a Welshman ... we[1]1 out of the way'. ${ }^{62}$ Despite the opprobrium blacklegs attracted, for many miners with impairments, like those without, the opportunity to make money as strike-breakers was just too enticing to shun. Moreover, although hated by striking miners, men like Edwards and 'Blind Davy' were probably quite attractive to employers determined to defeat unionism. Both men may have had impairments, but they also seem to have been workers with prior experience of mine work. During a strike, such experience was often at a premium as labourers with any kind of familiarity with mining could be very hard to find. Recalling the strike of 1844 in north-east England, coal viewer Ralph Elliott reported that the inexperienced Irish labourers imported to break the strike 'were so awkward at the work' that 'they could scarcely earn what their food 
cost us'. ${ }^{63}$ The economics of strikes, then, may have improved the position of disabled miners in the labour market and allowed them to command better wages than they could in less turbulent circumstances.

Strikes were not the only form of industrial action practised by mineworkers. Other less extreme and disruptive methods were used to influence the terms of work at nineteenth-century collieries. A common tactic employed by colliers, especially in Scotland and north-east England, was the restriction of output. By limiting production, mining unions aimed to manipulate the price of coal, and hence miners' wages, while simultaneously maximising the number of their members in work. ${ }^{64}$ As Victorian commentators remarked, this policy had a levelling effect in that it allowed less productive miners to earn the same as the most productive. This is because it forced miners capable of producing more than the set limit to work below full capacity, while ensuring good wages for those who struggled to reach higher production quotas (due to the inflated piece-work rates the policy encouraged). Writing in the 1840s, Mines Inspector Tremenheere outlined the policy of restriction then practiced by Scottish colliers and commented on its effects. It was based, he claimed, 'on the irrational principle of allowing no one man to do more work than another; of forcing an unnatural equality of earnings on the young and the old, the strong and the weak, the industrious and the idle'. ${ }^{65}$ Despite Tremenheere's disapproving tone, his observation clearly suggests the potential benefits of restriction for 'disabled' miners. Where restriction of output was in force, noted an official from Clyde Iron Works in 1845, older 'failing men' who normally relied on the assistance of their sons and others could produce as much coal as others of greater strength. A decade later, a 'gentleman of long experience' in the Scottish coalfield similarly affirmed that where restriction was practiced 'infirm old men' were able to earn the same pay as much stronger young colliers. ${ }^{66}$

Restriction was favourable for disabled miners in other ways too. As Colls has noted, union limits on output also facilitated 'the "carrying" of men who needed help' ${ }^{67}$ In other words, because some miners worked below full capacity, there were workers underground with spare time and energy on their hands to help less able colleagues. Restriction, then, mirrored the 'protective mutuality' practised by other workers in industrialising Britain. ${ }^{68}$ Recognising that restriction potentially helped miners with impairments make a living from mining also illuminates how industrial politics could shape the 'somatic flexibility' available to them discussed in Chapter 1. For many miners, their ability to work in mining was often just as much about the political conditions at their pits as it was about the state of the economy or their physical capacity for hard labour. 
On the whole, despite the advantages some disabled mineworkers enjoyed during periods of industrial conflict, protracted disputes between mine owners and their employees tended to cause severe hardships for mining families. Such hardships often affected disabled people particularly badly. In matters of industrial politics, courts commonly upheld the interests of mine owners and their representatives at the expense of workers. As we have seen, judges frequently imprisoned miners for defying employers and Edward Rymer's experiences indicate that men with impairments also shared this fate. Yet the courts were not the only state institutions used to discipline insubordinate or troublesome mineworkers. Sometimes the Poor Law was also utilised as a weapon in industrial disputes, and poor relief withheld from striking miners. ${ }^{69}$ While local welfare officials had a legal duty to relieve destitution, the Vagrancy Act of 1824 allowed for the punishment or denial of relief for those who refused work they were capable of performing. This made it legally permissible for Poor Law officers to deny public welfare to strikers or workers who refused to participate in strike-breaking. For example, in 1875 the Merthyr Tydfil Board of Guardians turned down an application for relief from a number of colliers from the Plymouth and Cyfarthfa works because the applicants would not accept work at a nearby colliery at Dowlais. The reason for the men's refusal was that work there had already been 'refused by the Dowlais Colliers', who were in dispute with their employer, and they did not want to undermine the cause of their fellow miners. ${ }^{70}$ Mineworker solidarity was clearly something Merthyr Tydfil welfare officers did not want to be seen supporting.

Examples like this reveal the politicised nature of welfare provision in Britain's coalfields. As Jamie Bronstein has observed, industrial paternalism in nineteenth-century Britain was based on the expectation that workers in need of medical care or financial support showed deference and gratitude to their benefactors and social betters. ${ }^{71}$ By resisting the will of their employers, strikers were the antithesis of the 'good' workers worthy of kindness and compassion mine owners sought to cultivate. Consequently, miners in dispute with their employers were more likely to be regarded as enemies to be crushed than people who 'deserved' help. As the preceding chapters have shown, it is inaccurate to automatically equate disability with dependency. Nevertheless, physical impairment did cause financial difficulties for many mining families and these could be ruthlessly exploited by mine owners who sought to defeat unionism.

Determined mine owners frequently stopped sickness benefits, or smart money payments to injured workers when they were in dispute with their employees. Such was the case with Thomas Lawton, a seventeen-year-old 
who had been badly burnt in a mine explosion in south Durham. Because of his injuries, Lawton had been unable to work for half a year and had received smart money during his period of incapacity. When his pit community got caught up in the industrial turmoil sweeping the region in 1831, however, his previously benevolent employer had a change of heart and stopped payments. Although Lawton had been off work and could not, therefore, practically go on strike, the fact that his fellow workers chose to do so was enough for his employer. $^{72}$

As this case shows, mine owners were often prepared to use any means available to destroy the morale of mining communities during strikes. The vindictiveness some owners and their managers showed towards those with the temerity to challenge them frequently impacted on disabled people. In 1853, Edward Richardson was one of several men at Seaton Delaval Colliery who lost their jobs for striking. Perhaps wishing to make a special example of Richardson, who had been a union agitator during the 1844 strike, the colliery agent chose to punish the dismissed worker's family further by withdrawing the smart money paid to Richardson's son, Matthew, a hewer at the colliery who had been injured in an accident some months before. When Richardson went with Matthew, 'who was then walking on crutches' to ask 'what he intended to do with his son who was disabled from work', the agent replied 'we have nothing to do with you or your son, you have brought it all on yourself, you might have been in a better situation than you are, had you looked towards your own interests'. ${ }^{73}$ In north-east England, owners continued to use smart money as a weapon in industrial conflict like this into the 1880 s and beyond. ${ }^{74}$

While striking mineworkers did not use disabled people as pawns in their industrial disputes in quite the same way as some employers did, their actions could undermine the well-being of injured colleagues on occasions. In the heat of battle with intransigent and ruthless mine owners, labour leaders were often willing to sacrifice the welfare of disabled people to achieve victory. It was not uncommon, for instance, for cash-strapped unions to suspend or reduce sickness benefits to facilitate the continued support of striking miners. ${ }^{75}$ Some friendly societies might similarly come under financial pressure during industrial unrest. In the first half of the nineteenth century, the distinction between trade unions and friendly societies was not always clear-cut. During industrial disputes mine owners and their supporters, like the pseudonymous writer 'Scrutator', commonly complained that friendly societies were really unions in disguise, used to promote collective action. In a pamphlet published in 1832, Scrutator reflected on the miners' strike of the previous year and argued that a friendly society supposedly set up for the 'relief of the sick or the support of 
the aged' had actually been used to fund strikers in what he contemptuously termed their 'unmanly slothfulness'. ${ }^{76}$

Despite the partisan nature of his comments, Scrutator had a point. Striking miners did sometimes utilise friendly society funds to support themselves, especially during lengthy disputes such as the strikes in north-east England of 1831 and 1844. According to a report by the Inspector of Mines, after exhausting their own resources, including selling or pawning personal belongings, strikers in 1844 were reduced to such a desperate state that they broke up their 'benefit clubs' and used the funds for their immediate support. This obviously had a very serious impact on the sick and injured miners who relied on club benefits to maintain themselves and their families. As the inspector realised, moreover, this was not a short-term problem. It would take years before the friendly societies involved replenished their funds to pre-strike levels, if ever. ${ }^{77}$ As prospective members with pre-existing medical conditions were usually barred from joining friendly societies, this situation was a major blow to many people with impairments in the coalfield who had depended on assistance from these clubs. Unless the societies resumed business and accumulated sufficient funds again, they were unlikely to ever receive cover under similar schemes in the future.

Friendly societies were also used by mine owners as a vehicle for achieving supremacy in industrial politics. Govan Colliery Friendly and Free Labour Society, instituted in 1826 on the insistence of the colliery's proprietor, ironmaster William Dixon, was regularly held up as a model for promoting an obedient mining workforce. Dixon had recently defeated a strike by mineworkers and was determined to eliminate any prospect of future disruptions at his colliery. After 1826, all workmen employed at his pit were required to join the new society. As its name made clear, the society was for the benefit of free (as opposed to unionised) labour only. In line with other mine owner-encouraged pit clubs of the time, such as Hetton Colliery Agents and Workmen's Friendly Society, the Govan Society expressly prohibited trade union members from joining. By barring unionists from the society while simultaneously making membership of the scheme a condition of employment, Dixon created a significant barrier to the establishment of an effective union at his colliery. For those who joined the society, moreover, any suspicion that they were even a little involved in union activism risked jeopardising their access to sickness and injury benefits in the event of incapacity. In return for their loyalty to their employer, members were offered security against strikes as well as sickness, with the society guaranteeing payment of benefits to members unable to work due to intimidation. ${ }^{78}$

During his battle with striking miners in 1825-26, out of which his plans for 
a Free Labour Society grew, Dixon employed a dual strategy to achieve victory. As other British colliery owners did repeatedly throughout the nineteenth century, Dixon employed blackleg labour to break the strike and evicted striking miners from company-owned housing. Evictions freed up accommodation to house imported strike breakers and aimed to undermine the resolve of employees who refused to return to work. ${ }^{79}$ This tactic was particularly used by employers during miners' strikes in Scotland and north-east England, where colliery-provided housing was more prevalent than in south Wales. ${ }^{80}$ Many mine owners were prepared to do whatever it took to forge a docile and obedient labour force - even if that meant throwing vulnerable people out of their homes. Recounting employer tactics during the strike of 1844 in northeast England, Fynes wrote that ' $[\mathrm{w}]$ holesale turning to the door commenced in almost every colliery village; pregnant women, bedridden men, and even innocent children in the cradle were ruthlessly and remorselessly turned out.' In his view, the eviction of 'the aged, the sick, and the feeble women from the homes of their childhood' was part of a deliberate strategy by employers to provoke striking miners to 'break the peace' so that the full force of the law could be brought down upon them. Among those evicted at Pelton Fell were an 'old blind woman, 88 years of age, who was left exposed to the cold and rain', while at another colliery 'a young man to whom a misfortune had happened was ruthlessly put to the doors' ${ }^{81}$

Families turned out of their colliery-owned accommodation sometimes found shelter in the homes of friends, relatives or charitable neighbours. Such sources of assistance were inadequate to meet the needs of everyone evicted during particularly bitter and protracted disputes. During the dispute described by Fynes, many striking miners and their families were forced to camp by roadsides in makeshift shelters like the one pictured in the Illustrated London News in August 1844 (Figure 5). ${ }^{82}$ The image of homeless strikers shivering in encampments became one of the most powerful symbols of the 1844 strike. 'It is true that the masters had a right to do what they liked with their own,' wrote Fynes, 'but on the score of humanity and fellow-feeling they might have refrained from turning their old servants to the doors till they had new ones ready to occupy their places.' Throughout Durham and Northumberland 'there were thousands of cottages tenantless, whilst their late inmates were camping in the open air, exposed to the inclemency of the weather'. It was, concluded Fynes, 'a cruel and dastardly revenge'. ${ }^{83}$

The depiction in the Illustrated London News of a man sitting outside a makeshift shelter holding a crutch, used the figure of the disabled miner to stand for the sufferings of the evicted in general. For supporters of the strike such as Fynes, eviction of the 'weak', pregnant, sick and old broke a moral 


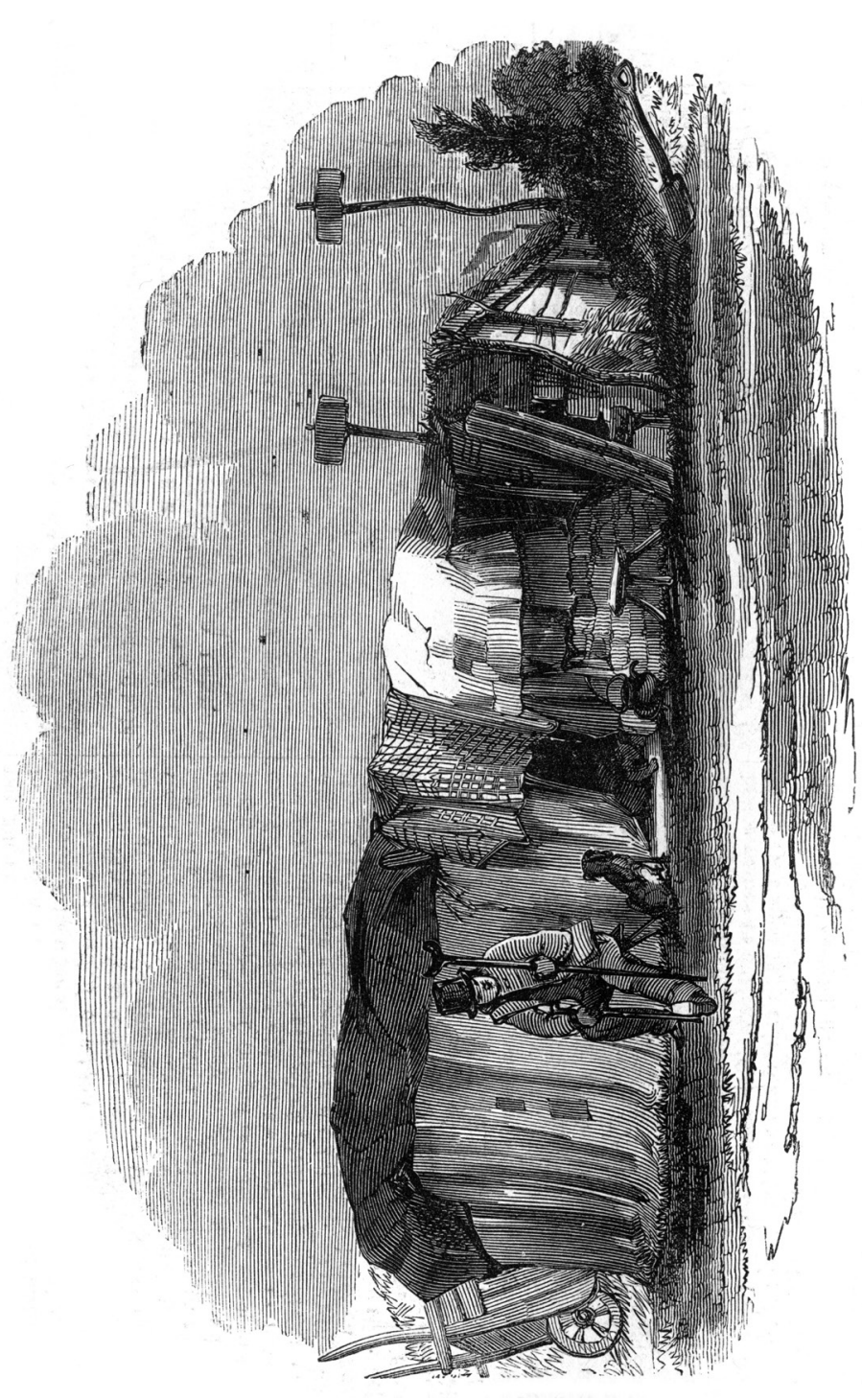

10

David M. Turner and Daniel Blackie - 9781526125774 
contract that held that masters should behave with compassion towards the vulnerable in pit communities. Since employers had often demonstrated their paternalist care for their workers by allowing widows and injured mineworkers to stay in company housing after they had been injured, the depiction of a disabled miner turned out during the strike shows how easily such benevolence might be withdrawn. It was a tactic used again in later disputes. For example, in November 1865, an anonymous writer and possible participant in a long-running strike at Cramlington Colliery in Northumberland informed the Home Secretary that the families of striking miners, including those containing 'the blind, the lamed, and the sick', had been forced from their homes. Among those evicted, for example, was 'one poor creature who was in the habit of taking fits'. ${ }^{84}$

Highlighting the sufferings of disabled people during industrial conflicts was undoubtedly a powerful means of criticising the cruelty of employers and their supporters. In Fynes' opinion, such behaviour was 'unmanly', went against the principles of Christian charity and was unpatriotic conduct from men 'with British hearts beating in their bosoms' ${ }^{85}$ Published in 1873, Fynes' account of the 1844 strikes echoed coverage of strikes in late nineteenthcentury newspapers which used sensationalist images of suffering, particularly hungry wives and children, to evoke sympathy for the victims of industrial conflict. Stories of the 'vulnerable' members of coalfield communities receiving equal 'punishment' to the men on strike, were clearly designed to have an emotional impact. ${ }^{86}$

Nevertheless, although there is evidence that disabled mineworkers may have fared especially badly during industrial disputes, such shared hardships may have allowed disabled miners to regard their 'sufferings' in a positive light. Although some may not have actually been working at the time strikes commenced, the extra difficulties they endured because of poor industrial relations may have allowed disabled miners to feel solidarity with their mining colleagues and part of the wider struggle in which their communities were engaged. The attitude of striking miners' wives is suggestive in this regard. Although they themselves were not on strike, strikers' wives were active participants in coalfield industrial disputes. In the early 1840s, an eyewitness to a strike of Staffordshire miners noted the great 'distress' they experienced and marvelled at the steadfastness of their wives in the face of such difficulties. 'The women, particularly,' he observed, 'were exceedingly inveterate in urging their husbands to hold out, saying, that they would rather live on potatoes and salt than give in.' Sacrifice and suffering enabled these women to show their commitment to the cause and membership of their working-class community. There is no reason to assume that the same did not hold true 
for disabled people caught up in the communal hardships associated with industrial action. ${ }^{87}$ Indeed, the ruthless and deliberate manner in which some mine owners targeted disabled people suggests employers certainly regarded them as aligned with defiant miners and therefore worthy of punishment. By sanctioning the breakup of benefit clubs during strikes, labour leaders similarly seem to have viewed sick and injured miners as participants in class struggle who were also expected to make personal sacrifices for the greater good. Whether or not they actively sought it, then, many disabled people in mining districts were undoubtedly united with mineworkers in a solidarity of suffering during industrial disputes that may have helped foster intense feelings of pride and belonging.

\section{Taking action: compensation and liability}

Sharing in the suffering of evicted strikers and providing moral support for those taking part in industrial action were indirect means by which those disabled from working could demonstrate solidarity with their non-disabled neighbours. By the 1870 s a more direct form of action on the part of injured workers and their families - the right to seek compensation in cases where employer negligence may have caused disablement - became a topic of increasing debate. This culminated in the passage of the 1880 Employers' Liability Act, which clarified the legal right to redress on the part of those who might suffer injury or disablement at work on account of their employers' negligence.

In the eighteenth century the families of those who lost their lives in workplace accidents could bring a lawsuit for forfeiture of property if it could be proved that the employer was negligent. The law was amended in 1846 to give dependents a financial claim in cases of accidental death where employer negligence could be proved. This was reinforced by the 1850 Mines Inspection Act, which (following provisions made in the 1844 Factory Act) opened up the possibility that fines imposed on coal owners under the law might be used to compensate the relatives of workers killed in fatal mining accidents. ${ }^{88}$ For the most part, in spite of the large number of fatalities in mining, litigation proved too expensive for most miners to pursue against their much more powerful employers. ${ }^{89}$ Furthermore, the doctrine of common employment that stipulated that no legal action could be brought if an injury or fatality was caused by a co-worker (a 'fellow servant') to the injured party, made actions difficult to bring. The definition of a 'fellow servant' was so loose that it left open the possibility that defence lawyers might plausibly argue that managers were also in common employment with manual workers therefore undermining any claim for compensation workers and their families might bring. ${ }^{90}$ 
Although the 1850 Mines Inspection Act did not result in a large number of compensation claims, the law may have encouraged some miners and their representatives to push for similar legal rights to seek financial redress for workers injured at work as for those killed on the job. In 1854, for example, as the 1850 Act came up for renewal, the Northumberland and Durham Miners' Association petitioned the Home Secretary to empower mines inspectors 'to institute proceedings at Law to recover damages' from mine owners for the 'death or injury to any miner ... caused by the neglect of the owners or their agents'. In such cases, the association urged, any awarded damages ought to go 'to the party injured'. ${ }^{11}$ Given the costs of litigation (estimated at a minimum of $£ 30$ ), the association proposed that the state should shoulder the financial burden, citing the fact that factory inspectors already had the power to bring legal actions on behalf of injured workers and their families. ${ }^{92}$ While the miners' calls were rejected on this occasion, further demands for more effective compensation legislation resurfaced in the aftermath of the shocking Hartley Colliery disaster of $1862 .^{93}$

Despite the considerable barriers, some injured mineworkers and their supporters did seek compensation from their employers through the courts. Bronstein, for example, cites the mid-nineteenth-century case of a Scottish collier boy who was awarded damages after his leg was amputated following an accident caused by his employer's neglect of safety. ${ }^{94}$ Successes like this, however, were quite rare. More typical of the experiences of disabled mineworkers before the courts was that of Ayrshire miner Thomas Mclachlan. In 1855 Mclachlan suffered a brain injury after a 'fire lamp' grate fell on him as he descended the pit. This had 'rendered [him] incapable of supporting himself and his family'. Being 'obliged to go on the parish', Mclachlan sued the company that had employed him for $£ 1000$. The issue of liability hinged on whether the grate had been adequately secured, but in spite of the allegation that one of its four legs was 'either broken off or loose', the jury returned a verdict for the coal company after just 'a few minutes deliberation'. The press report of this case referred to it as 'another coal-pit accident action', suggesting that, although their chances of success might be slim, other disabled miners around this time similarly had the courage to take on their employers in court. ${ }^{95}$ This was as true for other parts of Britain as it was for Scotland.

In 1858 a mine sinker in north-west England named Griffiths won $£ 100$ in compensation at the Liverpool Assizes after he was badly injured when a bucket fell down a mineshaft and hit him while he was working. The case, which again hinged on the argument that the 'machinery was imperfect and insufficient', received lengthy attention in the Colliery Guardian. This was sympathetic to mine owners and its coverage of the judgement suggested that 
Griffiths' victory posed a significant challenge to their usually successful efforts to avoid liability for workplace accidents. Believing the case set an important legal precedent, the Colliery Guardian urged its readers to learn lessons from the lawsuit. Employers ought to take the utmost care in ensuring that safety equipment was used and in good working order at their pits and that 'all proper regulations' were enforced. If they did not, there was a great danger that litigious miners and their unions might abuse the law 'just as the law for the protection of railway passengers is often perverted into the means of extortion' by people injured in railway accidents. The journal also restated the commonly held view that workmen were paid for the risk-taking their jobs entailed as well as the labour they performed. Given this, it implied, the relatively high wages mineworkers received were compensation enough for any injuries they might sustain at work. Furthermore, as 'the great majority of colliery owners aid in providing their workmen with medical attendance and the means of subsistence when hurt under their employ', why would injured miners need to seek damages - they were already adequately provided for by their employers. Or so the Colliery Guardian thought.

Mineworkers like Griffiths clearly had a different opinion and in the second half of the nineteenth century increasing numbers of those hurt in mining accidents or their representatives began to seek legal redress - first in the courts and then through Parliament. When it reported the Griffiths case in April 1858, the Colliery Guardian observed that in 'some districts working colliers are amazingly fond of law'. It was due to this fondness for legal action that the Colliery Guardian reasoned Griffiths' example would embolden restive mineworkers to seek damages from their employers whenever someone was injured in a colliery accident. ${ }^{96}$ Such fears were ultimately unfounded as Griffiths' challenge to mine owners' legal supremacy proved short lived. Within a few months of his victory, Griffiths' employer's legal team managed to get the initial ruling overturned at a retrial by successfully invoking the fellow-servant rule to argue that the colliery was not liable for his accident. ${ }^{97}$ Griffiths' eventual defeat shows just how determined mine owners were to defend their advantageous position under the law and the superior resources they had at their disposal to do so. Against such opponents, miners faced an uphill struggle to secure recompense for injury. Yet, fight they did.

As Bartrip and Burman have argued, by the 1870s it was becoming evident that state regulation of coal mines and other dangerous workplaces could only go so far in reducing the risk of death or disablement. Other methods were also needed to improve safety. Echoing the argument of English pitmen who called for substantial increases in smart money during the great strike of 1844, lawmakers came to see the threat of compensation as a way of incentivising 
employers to take better care of their workers' health and safety. ${ }^{98}$ This change in attitude was reflected in the provisions of the Coal Mines Act of 1872. This consolidated mining regulations into a single law and indicates the trajectory of health and safety legislation relating to the sector after 1850 . By the early 1870 s, the principle that fines imposed on mine owners for breaching safety legislation could be used to compensate the relatives of those killed in mining accidents had expanded to include miners injured in the workplace - provided the accident was not the fault of the worker. To be sure, the 1872 Act did not give disabled mineworkers (or the relatives of those killed at work for that matter) an absolute right to compensation. Decisions regarding the use of fines for the benefit of accident victims or their families were left to the discretion of the Home Secretary. ${ }^{99}$ But the law did signal that policymakers were becoming increasingly concerned about industrial injuries as well as fatalities. It also indicated that, by the latter part of the nineteenth century, the British state had developed a two-pronged approach towards mining accidents that incorporated prevention and compensation. Thus, the likelihood of accidents happening was to be reduced through improved safety measures and, when they did occur, those affected were to be adequately compensated.

The growing pressure for legislation to clarify workers' right to legal redress in the event of employer negligence in the 1870s owed much to the extension of the electoral franchise in 1867, which increased the electorate by around 1.5 million people. It also reflected the growing confidence and ability of trade unions to speak with a united voice following the formation of the Trades Union Congress (TUC) in 1868. ${ }^{100}$ By 1880, mining unions had come to regard taking legal action on behalf of miners killed or hurt in accidents as part of their remit. For example, from 1870 the Durham Miners' Association ruled that in every case where a managers' negligence had caused the death of a member, the union should seek compensation through the courts. ${ }^{101}$ The TUC discussed a compensation bill in 1874 and 1875 and, in 1876, Alexander MacDonald, the president of the Miners' National Association and Liberal MP for Stafford, introduced a bill reflecting workers' demands for compensation to Parliament. ${ }^{102}$ Following strong opposition from mine owners, the bill was withdrawn and the question of employers' liability for accidents in the workplace referred to a select committee. But after the landslide Liberal victory in the 1880 general election, in which compensation had been an important issue, a bill was introduced that would become the Employers' Liability Act of September 1880. The passage of this legislation has received considerable attention from scholars, and it is not the place of this chapter to re-tell this story. ${ }^{103}$ However, the debates around compensation merit some discussion as they reveal contested responses to disabling injury. As people who profited 
from a dangerous trade, most coal owners opposed any tightening of the law that might make them financially liable for accidents in the workplace. Yet the debate was more complex than a simple pitting of the interests of 'capital' against those of 'labour'. Many workers shared employers' fears that new legislation would cost livelihoods and undermine existing systems of support for sick and disabled miners.

Those opposing legislation defended the principle of paternalist care that had provided support for injured miners for decades that, they argued, had fostered co-operation between masters and men. At the same time, they cast suspicion on those injured or disabled miners who might try to exploit any new law. Following a deputation of the Miners' Association to the Home Secretary to support Macdonald's first attempt to introduce a bill in 1876, the Liberal MP for South Durham, Joseph Pease, warned that legislation would 'provoke a feeling of antagonism between employers and employed', for it would often be impossible to determine who was to blame. Ignoring the fact that disputes over the provision of smart money and other benefits had at times themselves caused 'antagonism between employers and employed', Pease reasoned that '[i]f the master was to be responsible for every crushed finger, or anything of that kind, the "smart money" which was a great object to the men, would be taken away, and they would lose the help which they otherwise got when they were out of work.' ${ }^{\prime 04}$ A letter to the Colliery Guardian in 1878 warned that extending the law on compensation would merely amplify existing abuses of colliery sick funds as 'many of the lazy class of men try their best to abuse [the system] by endeavouring to force the visiting officer to believe that the ailment they are suffering from was produced by an accident in the pit', when on medical inspection it was proven to be the result of some 'organic disease'. Sick funds, it argued, were policed by the men themselves, who had an interest in preventing fraud as it threatened the solvency of the schemes to which they contributed out of their own wages. However, if a 'colliery proprietor' became solely liable for an injury a workman received 'all his fellow workmen would be only too willing to swear black was white in his favour'. ${ }^{105}$

Some politicians sympathetic to the coal trade sought to head off the Employers' Liability Bill by proposing their own solutions. These sought to avoid the potential for antagonism between employers and workers by extending into law the principle of co-operation exemplified in the permanent relief fund movement and other voluntary schemes. For example, during a parliamentary debate in June 1878 reviewing mining legislation, Newcastle MP Joseph Cowen proposed the creation of a fund similar to the one established for keelmen working on the River Tyne in the eighteenth century. Financed by a tax on coal and compulsory contributions from colliers, this 
fund would provide an income for disabled mineworkers unable to follow their occupations. Cowen pointed out that such a scheme would be in the public interest, as it would help reduce the poor rate. Glamorgan MP Hussey Vivian, a strong opponent of employers' liability legislation, similarly urged the Home Secretary to consider establishing a fund 'for the support of widows and children' of those killed in mining accidents. Macdonald disagreed, however, arguing that the financial consequences of mining disasters for their victims ought to be 'met by the providence of the people rather than by the funds of the State'. While he supported voluntary welfare schemes that encouraged miners to supply 'the wants of their family by their own foresight and thrift', Macdonald's opposition to using state funds to provide support for the injured and their families was based on a belief that such measures would allow employers to shirk their responsibilities towards their workforce. In his view, only a compensation bill would force employers to take their duties to ensure workers' safety seriously. ${ }^{106}$

Nevertheless, the potential costliness of compensation was a key issue for opponents of legislation. However much compensation was intended to reduce the costs of mining accidents to the public, some argued that it would inevitably place burdens on public finances since mine owners might face a glut of ruinous claims after large-scale disasters. ${ }^{107}$ Beyond this, employers and miners alike feared that an increase in lawsuits would cause bad blood that would sour industrial relations and halt the co-operation that had advanced as a result of initiatives such as the permanent relief fund movement. John Bryson, leader of the Northumberland Miners Association, told the crowd at the Northumberland Miners' Picnic in 1880 that it was better for miners not to risk losing their hard-won benefits and to press for changes to safety at a local level rather than through Parliament. ${ }^{108}$

Speaking alongside Bryson at that gathering was former miner Thomas Burt, now a Liberal MP, who argued that schemes such as the permanent relief fund, though admirable, were merely voluntary. For Burt, compensation legislation would place financial protection for workers seriously injured in the workplace on a much surer footing. ${ }^{109}$ Against the view of the disabled miner as fraudulent or responsible for his own injuries through carelessness stirred up by opponents of reform, trade union supporters of legislation spoke instead of the 'great sacrifice of life and injury to limb' caused by the 'industrial work of the country'. Speaking at the Durham Miners' Association's annual Gala in 1880 , the association's president, William Crawford, described this situation as a 'standing disgrace to civilisation'. 110

Just as trade unionists and other labour advocates had done in earlier decades, those in favour of an Employers' Liability Act used the familiar 
trope of disability as honourable sacrifice to advance their cause. They argued that, like soldiers wounded in battle, disabled miners had similarly been hurt performing a valuable and essential public service for which they ought to receive recompense as a matter of right. Mining was so important to national prosperity that those injured at work in the sector through no fault of their own deserved the respect, gratitude and support of the nation. Above all else, reformists wanted to use the state to ensure that employers were held accountable for the diseases and injuries for which their industries were responsible.

In theory at least, this is what the 1880 Employers' Liability Act delivered. The new law made an employer responsible when a worker was injured as a result of faulty or unsafe machinery that he had provided, or as a result of orders he or his representatives had given. ${ }^{111}$ In practice, however, the Act's provisions were limited. The burden of proof was on victims to show negligence, and compensation payments were only allowed to last for three years after an accident. Furthermore, many miners were encouraged to opt out of the provisions of the Act or join insurance schemes, in return for coal owners' continued support of accident funds. ${ }^{112}$ In December 1880, for example, twothirds of the membership of the Lancashire and Cheshire Miners' Permanent Relief Society voted in favour of coming to an agreement with employers not to pursue claims under the Employers' Liability Act in return for an increase in 'disablement' pay from eight to ten shillings per week. ${ }^{113}$ Indeed, as Bartrip and Burman have argued, many miners viewed the legislation as largely symbolic, a means of encouraging mine owners to commit to bettering safety rather than as a practical scheme to compensate disabled workers. ${ }^{114}$ While the Employers' Liability Act of 1880 set a precedent for subsequent and more comprehensive compensation legislation in the immediate aftermath of its enactment, provisions for disabled miners still rested primarily on local, voluntary initiatives.

\section{Conclusion: a legacy of exclusion?}

Disability has rarely featured in histories of labour and industrial politics in nineteenth-century Britain. However, as this chapter has shown, the recognition that mining produced injury on a significant scale became a powerful driver of industrial regulation at a national level and affected industrial relations within the coalfields. As the voices of labour became louder during the nineteenth century, the 'sufferings' of the disabled miner were used to hold employers to account for poor working conditions, push for legislative responses to improve health and safety, and to rally the labouring classes to 
fight oppression. This rhetoric illustrates powerfully the place of disability in fostering working-class mutuality, reflected further in trade unions' own efforts to establish sick funds to help their members in times of need. Unions, particularly in north-east England, played an important role in holding employers to account for the payment of paternalistic benefits to disabled mineworkers such as smart money. By the 1870s, a joint committee of the Durham Coal Owners' Association and the Durham Miners' Association was meeting regularly to discuss worker grievances, including disputed payments of smart money to the sick and injured. ${ }^{115}$ By the end of our period, unions were also helping miners and other workers seek redress in the form of compensation for accidents in the workplace. However, unions were not always friends of disabled mineworkers. Their vision of working-class mutuality was one based on disciplined co-operation, and their support for the injured depended on the causes of their impairment. Miners with injuries caused by their own folly or misconduct, or whose behaviour threatened the safety of their colleagues, found themselves ostracised. Furthermore, mineworkers with impairments who might seek to exploit opportunities for work during strikes could find themselves treated with the same vilification as other blacklegs.

There can be no doubt that the susceptibility of coalminers to accidents at work was a far more pressing political matter by the end of our period than it had been in 1780. Over the course of the period the idea that workers in dangerous occupations willingly accepted the risks to their lives and limbs shifted, first in response to the employment of women and the very young (both of whom Victorians often regarded as less capable of making 'rational' decisions about risk by dint of their gender and age), and later as part of a new ideology of industrial efficiency that saw accidents as a threat to productivity. Although mining remained very dangerous, miners' mortality rates fell in the fifty years following the establishment of the Mines Inspectorate from 16.0 per thousand in 1851 to 11.5 per thousand in $1900-02 .{ }^{116}$ Better documentation of non-fatal as well as fatal accidents during this period was intended to force employers to confront their safety records, while attempts to tighten the law on employers' liability aimed to deter poor safety practices as much as provide compensation for the injured.

These measures were undoubtedly intended to benefit all coal workers and reduce occupational injury. Yet in the long run, these advancements in safety and support may have had consequences for the employment prospects of miners with impairments and chronic illness. In the first place, government health and safety initiatives undermined mineworkers' independence to determine their own ways of working. Policymakers realised that the creation of safe working conditions depended, to a large extent, on the regulation of labour. 
By 1872 mine safety legislation placed a legal responsibility on owners to establish 'special rules' for their employees. These were supposed 'to prevent dangerous accidents and to provide for the safety and proper discipline of the persons employed in or about' their mines. ${ }^{117}$ Managers and owners exploited legislators' injunction to ensure the 'proper discipline' of workers to its fullest. From the mid-1850s onwards, special rules were increasingly used at collieries to curtail the autonomy of mineworkers, much to their annoyance. To ensure compliance, moreover, supervision of the workforce increased. ${ }^{118}$ Such developments, while pertaining to the safety of all mineworkers, helped to reduce 'somatic flexibility' in mining and may have made it harder for some disabled miners to continue working.

Second, the development of compensation, intended to provide financial support for injured workers, may have actually exacerbated the troubles of older and disabled miners by encouraging their exclusion from colliery work. At the end of the century, Edward Rymer predicted that compensation laws for industrial workers were 'likely to be made an excuse in many quarters for seriously interfering with the labour of aged miners ... because it is said or surmised that old men would be less able to avoid danger, and thus become more liable to accidents in mines' ${ }^{119}$ Although the 1880 Employers' Liability Act was limited in its scope and had little immediate effect (because mining employers frequently reached agreements with their workers to contract out of the legislation - especially in areas like south Wales where accident rates were high) it encouraged unions to push for further reform. ${ }^{120}$ In 1897 the Workmen's Compensation Act introduced no-fault compensation that applied to any accident in the workplace irrespective of who was to blame.

The 1897 Act opened up the prospect of compensation for more disabled workers than ever before. Fighting compensation claims became an increasingly important part of trade union business in the early twentieth century. But the expansion of compensation would affect disabled miners' employment prospects in ways that seemed to confirm Rymer's fears about exclusion. Insurance schemes set up after 1897 to cover employers for their potential losses in compensation claims, sometimes refused to cover disabled, older or generally weaker workers, which made employers less likely to take the 'risk' of employing such personnel. ${ }^{121}$ Ben Curtis and Steven Thompson have shown that very soon after the Workmen's Compensation Act came into force in July 1898, coal owners in south Wales dismissed as many as 1,000 older mineworkers on the pretext that they were especially prone to accidents. While the scale of such dismissals was exceptional, and probably reflective of the sour industrial relations in the south Wales coalfield during the prolonged 
strike of that year, similar occurrences happened elsewhere. ${ }^{122}$ Witnesses to a Home Office Departmental Committee on the operation of Workmen's Compensation in 1903 reported that 'weak', sick, old and maimed workers were widely regarded by both employers and workmen's representatives as being more prone to accidents and slower to recover from them, making employers reluctant to hire them. The committee's report, published in 1904, concluded that older men and partially disabled workers were finding it harder to find and retain employment as a result of the Workmen's Compensation Act. ${ }^{123}$ In the United States, where workmen's compensation laws had been established in an overwhelming majority of states by the early 1920s, the expense of insuring aged and partially incapacitated workers led to significant discrimination against such people in employers' hiring strategies, leading Rose to conclude that workmen's compensation represented a formative moment in the exclusion of disabled people from the workforce. While policy changes were by no means the only exclusionary force acting against the employment prospects of impaired people, she argues, they played a major role in forcing their marginalisation in the labour market. ${ }^{124}$

In early twentieth-century Britain, the question of whether compensation law, and other measures intended to benefit workers, changed the employment prospects of partially disabled workers, was more contested. For all those who argued that the laws worked against the interests of older or disabled employees, there were others in the labour movement, such as MP Keir Hardie, who maintained that compensation had little impact and it was in fact changes in technology or productivity norms, including a powerful rhetoric of worker efficiency, that served to exclude the less 'able'. Lack of consensus on the issue made the TUC unwilling to push for greater protection for these workers against discrimination. ${ }^{125}$ Indeed, in the wake of workers' compensation legislation, some mines continued to provide light work for injured miners, possibly in an effort to keep down compensation costs under the new laws. During the economic troubles of the inter-war period, however, such practices became harder to maintain. ${ }^{126}$ Ultimately, if the Employers' Liability Act and subsequent compensation legislation did not result in a wholesale displacement of disabled people from the world of work, these laws created a new rationale for disability discrimination that some employers found sufficiently persuasive to act upon. In an era of compensation, disabled workers faced renewed negative reflection on their capabilities, reliability and worth that saw them as posing a greater risk to their employers, their fellow workers and themselves. 


\section{Notes}

1 'Capital and Labour', Punch, v (1843), 49. For a discussion of this image and its broader context, see Celina Fox, 'The Development of Social Reportage in English Periodical Illustration During the 1840s and early 1850s', Past and Present, 74:1 (1977), 90-111, especially 97. Matthias Reiss, 'The Image of the Poor and the Unemployed: the Example of Punch, 1841-1939' in Andreas Gestrich, Steven King and Lutz Raphael (eds), Being Poor in Modern Europe: Historical Perspectives 1800-1940 (Oxford and Bern: Peter Lang, 2006), 389-415.

2 The Times, 29 April 1842, cited in Fox, 'Development of Social Reportage', 95.

3 Hansard, HC Deb 7 June 1842, vol. 63, cols 1320-53.

45 \& 6 Victoria Cap. XCIX An Act to Prohibit the Employment of Women and Girls in Mines and Collieries, to Regulate the Employment of Boys, and to Make Other Provisions Relating to Persons Working Therein, 10 August 1842; Angela V. John, By the Sweat of Their Brow: Women Workers at Victorian Coal Mines (London: Routledge and Kegan Paul, 1984); cf. Catherine Mills, Regulating Health and Safety in the British Mining Industries 1800-1914 (Farnham: Ashgate, 2010), 60.

55 \& 6 Victoria Cap. XCIX.

6 D. G. Paz, 'Tremenheere, Hugh Seymour (1804-1893)', Oxford Dictionary of National Biography, Oxford University Press, 2004; online ed. January 2008, http://www.oxforddnb.com/view/article/27695, accessed 16 April 2015.

713 \& 14 Victoria Cap. C., An Act for Inspection of Coal Mines in Great Britain, 14 August 1850; Mills, Regulating Health and Safety, chs 2 and 3. For subsequent renewals of the 1850 Act, see 18 \& 19 Victoria Cap. CVIII, An Act to Amend the Law for the Inspection of Coal Mines in Great Britain, 14 August 1855; 23 \& 24 Victoria Cap. CLI, An Act for the Regulation and Inspection of Mines, 28 August 1860; 25 \& 25 Victoria Cap. LXXIX, An Act to Amend the Law Relating to Coal Mines, 7 August 1862.

8 Mills, Regulating Health and Safety; Raymond Challinor and Brian Ripley, The Miners' Association: A Trade Union in the Age of the Chartists (London: Lawrence and Wishart, 1968), 209-29.

9 Steve Sturdy, 'The Industrial Body' in Roger Cooter and John Pickstone (eds), Companion to Medicine in the Twentieth Century (London and New York: Routledge, 2003), 218; John Williams-Searle, 'Courting Risk: Disability, Masculinity, and Liability on Iowa's Railroads, 1868-1910', The Annals of Iowa, 58 (1999), 37; Jamie L. Bronstein, Caught in the Machinery: Workplace Accidents and Injured Workers in Nineteenth-Century Britain (Stanford, CA: Stanford University Press, 2008), 29.

10 Sturdy, 'The Industrial Body', 220-1.

1135 \& 36 Victoria Cap. LXXVI, An Act to Consolidate and Amend the Acts Relating to the Regulation for Coal Mines and Certain Other Mines, 10 August 1872.

12 Sarah F. Rose, “Crippled” Hands: Disability in Labor and Working Class History', Labor, 2:1 (2005), 30, 41. 
13 John Benson, British Coalminers in the Nineteenth Century: A Social History (Dublin: Gill and Macmillan, 1980), 197; Roy Church, The History of the British Coal Industry Vol. 3: 1830-1913: Victorian Pre-Eminence (Oxford: Clarendon Press, 1986), 674.

14 Alan B. Campbell, The Lanarkshire Miners: A Social History of Their Unions, 1775-1874 (Edinburgh: John Donald, 1979), 62.

15 John Benson, 'English Coal-Miners' Trade-Union Accident Funds, 1850-1900', Economic History Review 28:3 (1975), 401-12; James A. Jaffe, 'The State, Capital, and Workers' Control during the Industrial Revolution: The Rise and Fall of the North-East Pitmen's Union, 1831-2', Journal of Social History, 21 (1988), 728.

16 Benson, 'English Coal-Miners' Trade-Union Accident Funds', 405-7.

17 TNA, FS 28/8 Durham Miners' Association, 1872-1914, Rule book.

18 National Archives of Scotland, FS7/1, Rules of the Larkhall Miners' Mutual Protection, Accident and Funeral Association, 8 December 1874, 2, 4.

19 Bronstein, Caught in the Machinery, 120.

20 John Benson, 'Coalminers, Accidents and Insurance in Late Nineteenth-Century England', in Bernard Harris (ed.), Welfare and Old Age in Europe and North America: The Development of Social Insurance (London: Pickering \& Chatto, 2012), 22.

21 Northumberland Archives, 2/DE.4.6/39, Letters from John Crooks, 1788-96, Hartley Colliery Strike and Payment to Injured Miners, 1793.

22 Indeed, as Benson notes, smart money was unique to north-east England and 'did not exist elsewhere' in the country. Benson, 'Coalminers, Accidents and Insurance', 22.

23 United Association of Colliers, A Voice from the Coal Mines, Or, a Plain Statement of the Various Grievances of the Pitmen of the Tyne and Wear: Addressed to the Coal Owners, Their Head Agents, and a Sympathizing Public (South Shields: J. Clark, 1825), 28.

24 Lloyd's Weekly Newspaper, 23 June 1844, 5.

25 Ibid; The Times, 22 May 1844; 'The Pitmen's Strike', The Newcastle Courant, 10 May 1844.

26 United Association of Colliers, Voice from the Coal Mines, 9, 16, 21.

27 Ibid., 9.

28 PP 1849 [1109], Report of the Commissioner Appointed, Under the Provisions of the Act 5 \& 6 Vict., c. 99, to Inquire into the Operation of that Act, and into the State of the Population in the Mining Districts, 1849, 16.

29 Bronstein, Caught in the Machinery, 147.

30 Marjorie Levine-Clark, “"The Entombment of Thomas Shaw:” Mining Accidents and the Politics of Workers' Bodies', Victorian Review, 40:2 (2014), 23.

31 Challinor and Ripley, The Miners' Association, 209-29; Mills, Regulating Health and Safety, 103; A. J. Taylor, 'The Miners' Association of Great Britain and Ireland, 1842-48: A Study in the Problem of Integration', Economica, 22:85 (1955), 59. 
32 Jamie L. Bronstein, 'The Hartley Colliery Disaster', Victorian Review, 40:2 (2014), 11. The petition, combined with sympathetic public opinion, helped pressure MPs to introduce a change to the law in June 1862 to require collieries to have two shafts.

33 Challinor and Ripley, The Miners' Association, 128.

34 Frederick [sic] Engels, The Condition of the Working Class in England (London: Panther, 1969), 271, 274, 278.

35 The British Miner and General Newsman, n.s. no. 1, 7 March 1863. Bronstein, Caught in the Machinery, 79-80.

36 Ibid., no 5, 11 October 1862, 4.

37 Ibid., n.s., no. 13, 30 May 1863, 3.

38 Rose, “Crippled” Hands', 47; David T. Mitchell and Sharon Snyder, Narrative Prosthesis: Disability and the Dependencies of Discourse (Ann Arbor: University of Michigan Press, 2000), 47-64.

39 Church, British Coal Industry, 675.

40 Benson, British Coalminers, 189-90; J. H. Morris and L. J. Williams, The South Wales Coal Industry, 1841-1875 (Cardiff: University of Wales Press, 1958), 270; Mills, Regulating Health and Safety, 114-15.

41 Chris Wrigley, 'Unions', in Joel Mokyr (ed.), The Oxford Encyclopaedia of Economic History, Vol. 5 (Oxford \& New York: Oxford University Press, 2003), 154.

42 See also Dick Geary, 'The Myth of the Radical Miner' in Stefan Berger, Andy Croll and Norman Laporte (eds), Towards a Comparative History of Coalfield Societies (Aldershot: Ashgate, 2005), 43-64.

43 Colliery Guardian, 5 October 1867, quoted in Huw Beynon and Trevor Austrin, Masters and Servants: Class and Patronage in the Making of a Labour Organisation. The Durham Miners and the English Political Tradition (London: Rivers Oram, 1984), 31.

44 PP 1877 (285), Report from the Select Committee on Employers Liability for Injuries to their Servants; Together with the Proceedings of the Committee, Minutes of Evidence, and Appendix, 15.

45 John Williams-Searle, 'Cold Charity: Manhood, Brotherhood and the Transformation of Disability, 1870-1900', in Paul K. Longmore and Lauri Umansky (eds), The New Disability History: American Perspectives (New York: New York University Press, 2001), 157-86 (quote from 160).

46 John Rule, The Labouring Classes in Early Industrial England, 1750-1850 (London: Longman, 1986), 313-15, 331-40; Robert Duncan, The Mineworkers (Edinburgh: Birlinn, 2005), 133; Morris and Williams, South Wales Coal Industry, 274-84.

47 Rose, “'Crippled” Hands', 44.

48 Alan Campbell, for example, notes the frequent violence in Scottish mining strikes: Lanarkshire Miners, 77.

49 TNA, PC 1/18/19, Affidavit of Thomas Barnes, 20 March 1789.

50 The Times, 8 November 1842. 
51 For other examples of people injured in violence connected to industrial conflict in the coalfields, see: The Times, 9 May 1832; ibid., 2 August 1832.

52 TNA, HO 52/19, 216-217; David J. V. Jones, Before Rebecca: Popular Protests in Wales, 1793-1835 (London: Allen Lane, 1973), 86-113.

53 Edward Rymer, The Martyrdom of the Mine, Or, A 60 Years Struggle for Life (Middlesbrough, 1898), 8.

54 PP 1846 [737], Report of the Commissioner Appointed Under the Provisions of the Act 5 \& 6 Vict., c. 99, to Inquire into the Operation of that Act, and into the State of the Population in the Mining Districts, 1846, 15, 9.

55 Alexander Dalziel, The Colliers' Strike in South Wales (Cardiff: The Western Mail Offices, 1872), 171.

56 Andy Croll, 'Starving Strikers and the Limits of the "Humanitarian Discovery of Hunger” in Late Victorian Britain', International Review of Social History, 56 (2011), 104.

57 The Times, 20 April 1827.

58 Ibid., 3 October 1844.

59 Robert Colls, Pitmen of the Northern Coalfield: Work, Culture, and Protest, 17901850 (Manchester: Manchester University Press, 1987), 15.

60 For example, Campbell, Lanarkshire Miners; Rule, The Labouring Classes, 338-40; Morris and Williams, South Wales Coal Industry, 262-4.

61 TNA, HO 52/19, 216-17.

62 Richard Fynes, The Miners of Northumberland and Durham: A History of Their Social and Political Progress (Blyth: John Robinson, 1873), 111.

63 PP 1846 [737], 16

64 Campbell, Lanarkshire Miners, 51, 108-9, 264-6; Colls, Pitmen, 30.

65 PP 1844 [592], Report of the Commissioner Appointed Under the Provisions of the Act 5 \& 6 Vict. c. 99, to Inquire into the Operation of that Act, and into the State of the Population in the Mining Districts, 32.

66 PP 1845 [670], Report of the Commissioner Appointed Under the Provisions of the Act 5 \& 6 Vict. c. 99, to Inquire into the Operation of that Act, and into the State of the Population in the Mining Districts, 1845, 11; PP 1856 [2125], Report of the Commissioner Appointed Under the Provisions of the Act 5 \& 6 Vict. c. 99, to Inquire into the Operation of that Act, and into the State of the Population in the Mining Districts, 1856, 42.

67 Colls, Pitmen, 32.

68 John Belchem, Industrialization and the Working Class: The English Experience, 1750-1900 (Aldershot: Scolar Press, 1990), 16-17.

69 Duncan, The Mineworkers, 134; Challinor and Ripley, The Miners' Association, 137.

70 Glamorgan Archives UM/1/18, Merthyr Tydfil Board of Guardians Minutes, 16 March 1875. The legal right to relief for strikers is examined in Andy Croll, 'Strikers and the Right to Poor Relief in Victorian Britain: The Making of the Merthyr Tydfil Judgment of 1900', Journal of British Studies, 52 (2013), 128-52. 
71 Bronstein, Caught in the Machinery, 35, 46.

72 Benson, British Coalminers, 179.

73 Fynes, Miners of Northumberland and Durham, 139-40.

74 For example, Durham Record Office, D/DCOA 72, Durham Coal Owners' Association, Proceedings of Joint Committee, 30 September 1880.

75 Benson, 'English Coal-Miners' Trade-Union Accident Funds', 409-11.

76 Scrutator, An Impartial Enquiry into the Existing Causes of Dispute between the Coal Owners of the Wear and Tyne and Their Late Pitmen (Houghton-Le-Spring: Printed for the author by J. Beckwith, 1832), 6. For similar allegations about the strike made by owners themselves: Coalowners of the Rivers Tyne and Wear, Report by the Committee of the Coalowners Respecting the Present Situation of the Trade (Newcastle: Printed by W., E., and H. Mitchell, Newcastle, 1832), 6-7.

77 PP 1846 [737], 8; Jaffe, 'The State, Capital, and Workers' Control', 721.

78 'Articles of the Govan Colliery Friendly and Free Labour Society', PP 1851 [1422], Coal Mines. Reports of Messrs. Dunn, Dickinson, and Morton, Inspectors of Coal Mines, to Her Majesty's Secretary of State, 18-22. PP 1856 [2132], Report of the Commissioner Appointed under the Provisions of the Act 5 \& 6 Vict. c. 99, to Inquire into the Operation of that Act, and into the State of the Population in the Mining Districts, 1856, 37-41, 53-58; PP 1842 (381), Appendix to the First Report of the Commissioners. Mines. Part 1. Reports and Evidence from Sub-Commissioners, 356-9; Campbell, Lanarkshire Miners, 71; TNA, FS 1/120, 'Rules of the Hetton Colliery Agents and Workmen's Friendly Society', [Rule 3].

79 Campbell, Lanarkshire Miners, 71.

80 Benson, British Coalminers, 104-5.

81 Fynes, Miners of Northumberland and Durham, 74-5.

82 Challinor and Ripley, The Miners' Association, 135.

83 Ibid., 80.

84 TNA, HO 45/7692 Home Office: Registered Papers. Disturbances: Evictions at Cramlington Colliery, Northumberland (1865).

85 Fynes, Miners of Northumberland and Durham, 74.

86 Cf. Croll, 'Starving Strikers'.

87 PP 1843 [508], Midland Mining Commission. First Report. South Staffordshire, xxv. We are grateful to Jamie Bronstein for encouraging us to think about this possibility.

8813 \& 14 Victoria Cap. C, Section VIII.

89 Bartrip and Burman, Wounded Soldiers of Industry, ch. 4.

90 P. W. J. Bartrip, Workmen's Compensation in Twentieth-Century Britain: Law, History and Social Policy (Aldershot: Gower, 1987), 5.

91 TNA, HO 45/5547, Memorial of Northumberland and Durham Miners to the Home Secretary, 16 December 1854. Our emphasis.

92 Bartrip and Burman, Wounded Soldiers of Industry, 110.

93 Bronstein, Caught in the Machinery, 146.

94 Ibid., 103. 
95 Paisley Herald and Renfrewshire Advertiser, 4 August 1855.

96 'Damages from a Colliery Owner for Personal Injury', Colliery Guardian and Journal of the Coal and Iron Trades, 3 April 1858; Bronstein, Caught in the Machinery, ch. 5. On compensation and the railways see Audrey C. Giles, 'Railway Accidents and Nineteenth-Century Legislation: "Misconduct, Want of Caution or Causes beyond their Control”', Labour History Review, 76:2 (2011), 121-42; Michael Quick, 'Mid-Victorian Compensation Culture', Journal of the Railway and Canal Historical Society, 192 (2005), 110-17.

97 Griffiths v. Gidlow in E. T. Hurlstone and J. P. Norman, The Exchequer Reports: Reports of Cases Argued and Determined in the Courts of Exchequer \& Exchequer Chamber, vol. III (London: H. Sweet, W. Maxwell ,V. \& R. Stevens and G. S. Norton, 1859), 648-56.

98 Bartrip and Burman, Wounded Soldiers of Industry, 96.

9935 \& 36 Victoria Cap. LXXVI, Section 68.

100 Bronstein, Caught in the Machinery, 152-4.

101 Benson, British Coalminers, 200.

102 Ibid., 155.

103 The fullest accounts can be found in Bartrip and Burman, Wounded Soldiers of Industry, ch. 5; Bronstein, Caught in the Machinery, ch. 5.

104 Northern Echo, 22 May 1876.

105 'Compensation for Injuries Bill', Colliery Guardian, 27 December 1878.

106 Hansard, HC Deb 21 June 1878, vol. 241, cols 67-98. For more on the Keelmen's scheme, see P. H. J. H. Gosden, The Friendly Societies in England 1815-1875 (Manchester: Manchester University Press, 1961), 6.

107 Letter from Joseph S. Pease, The Times, 22 July 1880.

108 Northern Echo, 19 July 1880.

109 Ibid.

110 'The Durham Miners' Demonstration', Northern Echo, 2 August 1880.

11143 \& 44 Victoria Cap. 42. An Act to Extend and Regulate the Liability of Employers to Make Compensation for Personal Injuries Suffered by Workmen in Their Service, 7 September 1880; Bronstein, Caught in the Machinery, 164.

112 Bartrip and Burman, Wounded Soldiers of Industry, 161-4.

113 Glasgow Herald, 30 December 1880; Bartrip and Burman, Wounded Soldiers of Industry, 161.

114 Ibid., 164.

115 Durham Record Office, D/DCOA 72 Durham Coal Owners' Association, Proceedings of the Joint Committee, 1872-81.

116 Church, British Coal Industry, 584; cf. Benson, British Coalminers, 43.

11735 \& 36 Victoria Cap. LXXVI, Section 52.

118 Campbell, Lanarkshire Miners, 107; Colls, Pitmen, 37-8.

119 Rymer, Martyrdom of the Mine, 27.

120 Ben Curtis and Steven Thompson, "'This is the Country of Premature Old Men:" Ageing and Aged Miners in the South Wales Coalfield, c. 1880-1947', Cultural 
and Social History, 12:4 (2015), 598; Bartrip and Burman, Wounded Soldiers of Industry, 173.

121 Bartrip and Burman, Wounded Soldiers of Industry, 212.

122 Curtis and Thompson, 'This is the Country of Premature Old Men', 597; Durham Record Office, D/X 1005/21, correspondence to let aged or infirm men go at Chopwell Colliery, 10 September 1912.

123 Bartrip, Workmen's Compensation, 43.

124 Nate Holdren, 'Incentivizing Safety and Discrimination: Employment Risks under Workmen's Compensation in the Early Twentieth Century United States', Enterprise and Society, 15 (2014), 31-67; Sarah F. Rose, No Right To Be Idle: The Invention Of Disability, 1840s-1930s (Chapel Hill: University of North Carolina Press, 2017), 161-71, 224.

125 Bartrip, Workmen's Compensation, 52, 72; Sturdy, 'The Industrial Body'.

126 Mike Mantin, 'Coalmining and the National Scheme for Disabled Ex-Servicemen after the First World War', Social History, 41:2 (2016), 161. 